\title{
Effects of milk and milk constituents on postprandial lipid and glucose metabolism in overweight and obese men
}

\author{
Leonie E. C. van Meijl and Ronald P. Mensink* \\ Department of Human Biology, NUTRIM School for Nutrition, Toxicology and Metabolism, Maastricht University Medical \\ Centre +, PO Box 616, 6200 MD Maastricht, The Netherlands \\ (Submitted 26 July 2012 - Final revision received 30 October 2012 - Accepted 31 October 2012 - First published online 3 January 2013)
}

\begin{abstract}
Studies have suggested that two major milk constituents, casein and Ca, favourably affect postprandial responses. However, effects of milk on postprandial metabolism are unknown. We therefore investigated effects of using milk with a fat-containing meal on lipid and glucose responses in overweight men. To identify the constituent responsible for possible effects, we also studied responses to Ca and protein. A total of sixteen men (BMI $>27 \mathrm{~kg} / \mathrm{m}^{2}$ ) participated in four postprandial tests. They consumed a breakfast (44 g of fat) plus a drink: a control drink, low-fat milk or a protein and Ca drink $(500 \mathrm{ml})$. Blood samples were taken before the meals and at regular time points during $6 \mathrm{~h}$ thereafter. Compared with control, the incremental AUC (iAUC) for serum TAG was increased by $44 \%$ after the protein meal $(P=0 \cdot 015)$. Although the iAUC were not different $(P=0.051)$, peak glucose concentrations were reduced by $24 \%$ after protein intake, as compared with control $(P=0.021)$. The decrease of $18 \%$ after milk intake did not reach statistical significance. Compared with the milk meal, the iAUC for insulin was $52 \%$ lower after the control meal $(P=0.035)$ and $51 \%$ after the protein meal $(P=0 \cdot 005)$. The present results indicate that the intake of milk with a fat-containing meal enhances postprandial TAG and insulin responses and may blunt glucose increases. The protein fraction of milk seems to be the main determinant for the effects on TAG and glucose. Ca did not change any of the postprandial responses.
\end{abstract}

\section{Key words: Human nutrition: Milk: Protein: Calcium: Postprandial metabolism}

Postprandial hyperlipidaemia and hyperglycaemia are strongly associated with $\mathrm{CVD}^{(1,2)}$. In fact, postprandial changes in plasma TAG and glucose concentrations might be more strongly associated with CVD risk than their fasting concentrations $^{(3,4)}$. Further, high fasting glucose concentrations are predictive for post-meal glucose excursions ${ }^{(5)}$ and those of fasting TAG for postprandial hyperlipidaemia ${ }^{(6)}$, which may explain why patients with the metabolic syndrome often have a disturbed postprandial metabolism ${ }^{(7)}$. As people in the Western world are in a non-fasting state for most of the day, these are important findings.

The macronutrient composition of a meal is an important determinant of the postprandial response. High-fat meals have been found to increase plasma TAG concentrations ${ }^{(8)}$, to impair endothelial activity and function ${ }^{(9)}$ and to increase markers of inflammation ${ }^{(10)}$. However, Westphal et al. ${ }^{(11)}$ have shown that adding glucose to a high-fat meal resulted in a delay and reduction of postprandial lipaemia. Casein had an even stronger effect: chylomicron responses were further reduced and delayed, which could not be explained by gastric emptying time. Further, concentrations of C-peptide and insulin were elevated during the post-absorptive phase (4-8h) after the casein-containing meals. Whether milk and other dairy products have comparable effects on postprandial metabolism, as has milk protein alone, is not known. Furthermore, it has been reported that increased $\mathrm{Ca}$ intakes from dairy products reduced chylomicron TAG concentrations after a meal ${ }^{(12)}$. However, effects of $\mathrm{Ca}$ on other postprandial responses have not been studied before. In the present study, we therefore investigated the effects of adding low-fat milk to a high-fat breakfast on postprandial lipid and glucose metabolism in overweight and obese subjects. To evaluate which of the dairy components may be responsible for possible effects, we also studied the postprandial effects of milk protein and Ca, two major milk constituents.

\section{Methods}

\section{Study population}

Subjects were recruited in Maastricht and surroundings by advertisements in local newspapers and posters in the hospital and university buildings. People who were interested to participate were informed about the purposes

Abbreviation: iAUC, incremental AUC.

*Corresponding author: R. P. Mensink, fax +31 4336709 76, email r.mensink@maastrichtuniversity.nl 
and requirements of the study, and all gave their written informed consent before they entered the screening procedure. The study was approved by the Medical Ethical Committee of the Maastricht University Medical Centre and was registered on 8 June 2009 at ClinicalTrials.gov as NCT00917878.

Subjects were invited for the screening procedure when they met the following inclusion criteria: male; aged 18-70 years; non-smoking; $\mathrm{BMI}>27 \mathrm{~kg} / \mathrm{m}^{2}$; no active CVD, familial hyperlipidaemia, inflammatory diseases or other medical conditions that might interfere with the study outcomes; no abuse of alcohol or drugs; and stable body weight during the past 3 months. During two screening visits, body weight, height and blood pressure were measured and a fasting blood sample was taken to determine serum lipid and lipoprotein concentrations. A total of sixteen men were enrolled in the study (Table 1). They were asked not to change their dietary habits, use of alcohol and level of physical exercise during the study. They were also requested to record any signs of illness, use of medication or other important details during the study period in a diary. All men completed the study.

\section{Study design and intervention}

The study consisted of four test days, which were separated by a washout period of at least $3 \mathrm{~d}$. On each test day, subjects received a different test meal in randomised order, and participated in a postprandial test. Subjects were asked not to perform any strenuous physical exercise and not to consume alcohol on the day before testing. They were also asked to refrain from high-fat foods on the day prior to the test days. After an overnight fast, subjects arrived at the university by public transport or car. An intravenous cannula (Venfon ${ }^{\circledR}$; Becton Dickinson) was inserted into an antecubital vein and blood samples were collected for analysis of fasting concentrations of metabolic risk markers. Subjects were then requested to consume one of the test meals within $10 \mathrm{~min}$. Subsequent blood samples were drawn 15, 30, 45, 60, 90, 120, 180, 240, 300 and $360 \mathrm{~min}$ after meal consumption. Subjects were allowed to drink water ( $250 \mathrm{ml}$ ) directly after the $T=120$ and $T=240$ blood sample collections.

The test meals consisted of $168 \mathrm{~g}$ butter cake and $500 \mathrm{ml}$ of one of the four drinks (Table 2). In the milk intervention, subjects consumed skimmed milk ( $0 \%$ fat; Campina). All drinks contained an equal amount of lactose (DMV International).

Table 1. Baseline characteristics of the sixteen men (Mean values and standard deviations)

\begin{tabular}{lcc}
\hline Characteristics & Mean & SD \\
\hline Age (years) & 49.8 & 15.5 \\
BMI $\left(\mathrm{kg} / \mathrm{m}^{2}\right)$ & 31.2 & 3.6 \\
Systolic blood pressure $(\mathrm{mmHg})$ & 129 & 12 \\
Diastolic blood pressure $(\mathrm{mmHg})$ & 86 & 8 \\
Total cholesterol (mmol/l) & 5.58 & 0.87 \\
LDL-cholesterol (mmol/l) & 3.57 & 0.70 \\
HDL-cholesterol (mmol/l) & 1.23 & 0.27 \\
TAG (mmol/l) & 1.71 & 0.62 \\
Glucose (mmol/l) & 5.66 & 0.35 \\
Insulin (pmol/l) & 160 & 71 \\
\hline
\end{tabular}

The protein drink contained the same amount of protein (REFIT Total Milk Protein; DMV International) as the milk, while the Ca content (Lactoval; DMV International) of the Ca and protein drinks was equal to that of the milk. The amino acid compositions of all meals are provided as supplementary Table S1 (available online).

\section{Blood sampling and analyses}

Venous blood was sampled using a Vacutainer system (Becton Dickinson). Blood was drawn into serum separator tubes for the analysis of lipids and lipoproteins. After clotting at room temperature for at least $30 \mathrm{~min}$, serum was obtained by centrifugation at $1300 \mathrm{~g}$ for $15 \mathrm{~min}$ at room temperature and stored at $-80^{\circ} \mathrm{C}$. Further, blood was sampled into EDTA tubes for the analysis of insulin and NEFA concentrations and sodium fluoride (NaF) tubes were used for analysis of plasma glucose and amino acid concentrations. EDTA and $\mathrm{NaF}$ tubes were kept on ice until centrifugation at $1300 \boldsymbol{g}$ for 15 min at $4^{\circ} \mathrm{C}$. Plasma samples were snap-frozen in liquid $\mathrm{N}_{2}$ and stored at $-80^{\circ} \mathrm{C}$.

Fasting serum samples were analysed for concentrations of total cholesterol (CHOD-PAP method; Roche) and HDL-cholesterol (precipitation method; Roche). LDL-cholesterol concentrations were calculated using the Friedewald equation ${ }^{(13)}$. Concentrations of TAG, with correction for free glycerol, were determined in serum samples from $T=0,60,120,180,240,300$ and $360 \mathrm{~min}$ (GPO Trinder; Sigma Diagnostics). apoB-48 concentrations were determined in plasma samples from $T=0,120,240$ and 360 min by ELISA (Human Apo

B-48 kit; Shibayagi). NEFA concentrations were analysed in plasma samples from $T=0,60,120,240$ and $360 \mathrm{~min}$ (NEFA kit; WAKO).

Glucose concentrations (Horiba ABX) and insulin concentrations (RIA; Millipore) were measured in plasma samples from $T=0,15,30,45,60,90,120,240$ and $360 \mathrm{~min}$. Plasma amino acid concentrations were determined from blood samples obtained at $T=0,60$ and $120 \mathrm{~min}$, as described elsewhere ${ }^{(14)}$.

\section{Statistics}

Data are presented as mean values and standard deviations unless otherwise indicated. Fasting concentrations $(T=0)$ of the various parameters, as measured on the day of each test meal, were not statistically significant, as examined using univariate ANOVA. To evaluate the overall response of total TAG, apoB48, glucose, insulin and NEFA during the $6 \mathrm{~h}$ postprandial period, the incremental areas under the postprandial curve (iAUC) or decremental AUC were calculated using the trapezoidal rule. Maximal changes were calculated by subtracting fasting concentrations from the maximal or minimal value. Differences in iAUC and maximal changes between the test meals were tested for significance by univariate ANOVA followed by Bonferroni's correction for multiple comparisons. Changes in concentrations over time were analysed using linear mixed models, with diet and time as fixed factors and with diet $\times$ time as the interaction term. If the interaction term was not statistically significant, it was omitted from the 
Table 2. Composition of the test meals

\begin{tabular}{|c|c|c|c|c|}
\hline & Control & Milk & Protein & $\mathrm{Ca}$ \\
\hline Products/components & $\begin{array}{l}\text { Butter cake, } 168 \mathrm{~g} ; \text { water, } \\
500 \mathrm{ml} \text {; lactose, } 29 \mathrm{~g}\end{array}$ & $\begin{array}{l}\text { Butter cake, } 168 \mathrm{~g} ; \\
\text { milk, } 500 \mathrm{ml}\end{array}$ & $\begin{array}{l}\text { Butter cake, } 168 \mathrm{~g} \text {; water, } \\
500 \mathrm{ml} \text {; lactose, } \\
29 \mathrm{~g} \text {; milk protein, } \\
23.4 \mathrm{~g} ; \mathrm{Ca}, 1.3 \mathrm{~g}\end{array}$ & $\begin{array}{l}\text { Butter cake, } 168 \mathrm{~g} \text {; } \\
\text { water, } 500 \mathrm{ml} ; \\
\text { lactose, } 29 \mathrm{~g} ; \mathrm{Ca}, 2.3 \mathrm{~g}\end{array}$ \\
\hline \multicolumn{5}{|l|}{ Composition } \\
\hline Energy (kcal) & 864 & 948 & 948 & 864 \\
\hline Energy (kJ) & 3615 & 3966 & 3966 & 3615 \\
\hline Protein $(\mathrm{g})$ & 8 & 29 & 29 & 8 \\
\hline Carbohydrates (g) & 109 & 109 & 109 & 109 \\
\hline Mono- and disaccharides & 74 & 74 & 74 & 74 \\
\hline Of which lactose & 30 & 30 & 30 & 30 \\
\hline Fat $(\mathrm{g})$ & 44 & 44 & 44 & 44 \\
\hline $\mathrm{Ca}(\mathrm{mg})$ & 49 & 697 & 703 & 699 \\
\hline $\mathrm{P}(\mathrm{mg})$ & 100 & 600 & 407 & 353 \\
\hline
\end{tabular}

model, and the factors diet and time were tested for statistical significance. If significant, post hoc tests with Bonferroni's correction were carried out. For time, only comparisons were made relative to those of fasting concentrations. All statistical analyses were performed using SPSS 16.0 for Macintosh OS X package (SPSS). A $P$ value $<0.05$ was considered as statistically significant.

\section{Results}

\section{TAG and $a p o B-48$}

Changes in serum TAG concentrations during the postprandial phase did not differ significantly between the meals $(P=0 \cdot 186$ for meal effects; Fig. 1). Compared with fasting concentrations, all test meals increased serum TAG concentrations $(P<0.001$ for time effect), which reached peak concentrations after $180 \mathrm{~min}$ and had not returned to fasting concentrations after $360 \mathrm{~min}$. iAUC and maximal increases are shown in Table 3. Compared with the control meal, addition of protein to the meal significantly increased the iAUC by $44 \%(P=0 \cdot 015)$. The difference between the protein and $\mathrm{Ca}$ meals was nearly significant $(P=0 \cdot 062)$. The maximal increases in serum TAG concentrations were not different between the four meals $(P=0 \cdot 498)$. Fig. 2 shows apoB-48 concentrations after the test meals. Compared with fasting values, all test meals increased apoB-48 concentrations ( $P<0.001$ for time effect). Also, a statistically significant meal effect was found $(P=0 \cdot 016)$, related to differences between the milk and Ca meals $(P=0.030)$ and the protein and $\mathrm{Ca}$ meals $(P=0 \cdot 042)$. Compared with the milk meal, the Ca meal decreased the iAUC by $48 \%(P=0 \cdot 012$; Table 3). The maximal increases from fasting values were not statistically different between the test meals $(P=0.076)$.

\section{Glucose and insulin}

Plasma concentrations of glucose and insulin are provided as supplementary Figs. S1 and S2 (available online). Compared with fasting values, all test meals increased serum glucose concentrations ( $P<0.001$ for time effect), which decreased below fasting concentrations after about $180 \mathrm{~min}$. Changes between the meals, however, were not significantly different ( $P=0.947$ for meal effect). Glucose concentrations were maximally increased at $15 \mathrm{~min}$ after the consumption of the $\mathrm{Ca}$ and protein meals, and at $30 \mathrm{~min}$ after consumption of the control and milk meals. The meals did not change the iAUC significantly $(P=0.051)$, but did change the maximal increase in glucose concentrations $(P=0.004)$. The difference between the protein and control meals of $-24 \%$ reached statistical significance $(P=0.021)$. The decrease of $18 \%$ after milk intake did not reach statistical significance $(P=0 \cdot 111)$.

Insulin concentrations were maximal at $45 \mathrm{~min}$ after consumption of the test meals and had returned to fasting concentrations after $240 \mathrm{~min}(P<0.001$ for time effect). No meal effects were found $(P=0.585)$. Meal effects for the iAUC were significantly different $(P<0 \cdot 001)$. Compared with the control meal, the iAUC was $52 \%$ higher after the milk meal $(P=0.035)$. Also, the difference of $51 \%$ between the milk and protein meals reached statistical significance $(P=0.005)$. The maximal increases were not statistically different between the four test meals $(P=0 \cdot 227)$.

\section{NEFA}

Plasma NEFA concentrations significantly changed over time $(P<0 \cdot 001)$, but these changes were not affected by the

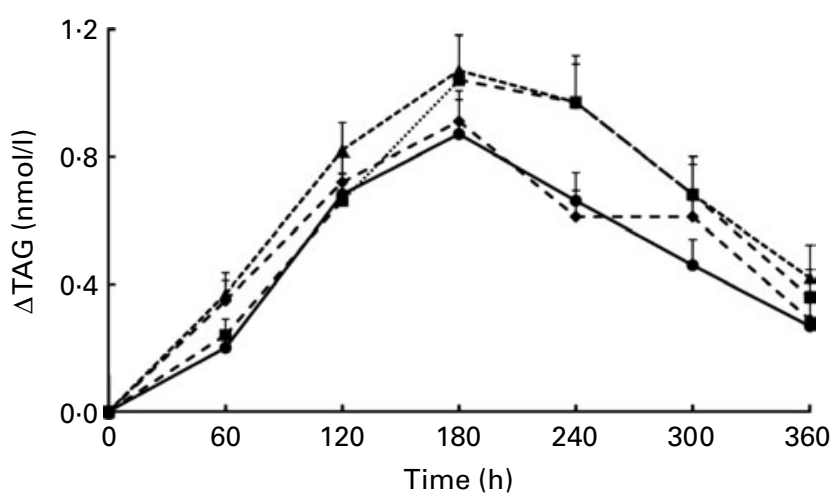

Fig. 1. Mean changes in serum TAG concentrations after consumption of the control, milk, protein, and calcium meals in a randomised crossover study with overweight and obese men $(n 16)$. Values are means with their standard errors and were analysed using linear mixed models. There were no significant meal $\times$ time interactions. Time effects were $P<0.001$ and meal effects $P=0 \cdot 186$. After Bonferroni's correction for multiple comparisons, all time points significantly differed from zero: $P<0.001$. - - , Control; .- $\mathbf{-}$, milk; $-\mathbf{\Delta}$-, protein; - - - calcium. 
Table 3. Incremental AUC (iAUC) and maximal changes from fasting concentrations

(Mean values and standard deviations)

\begin{tabular}{|c|c|c|c|c|c|c|c|c|c|}
\hline & \multicolumn{2}{|c|}{ Control } & \multicolumn{2}{|c|}{ Milk } & \multicolumn{2}{|c|}{ Protein } & \multicolumn{2}{|c|}{$\mathrm{Ca}$} & \multirow[b]{2}{*}{$P$ for meal effect } \\
\hline & Mean & SD & Mean & SD & Mean & SD & Mean & SD & \\
\hline \multicolumn{10}{|l|}{ TAG } \\
\hline $\mathrm{iAUC}(\mathrm{mmol} \times \mathrm{min} / \mathrm{l})$ & $181^{\mathrm{a}}$ & 71 & $226^{a, b}$ & 127 & $249^{b}$ & 97 & $202^{a, b}$ & 75 & 0.007 \\
\hline $\begin{array}{l}\text { Maximal change }(\mathrm{mmol} / \mathrm{l}) \\
\text { apoB-48 }\end{array}$ & 0.97 & 0.41 & 1.07 & 0.57 & $1 \cdot 16$ & 0.44 & $1 \cdot 11$ & 0.57 & 0.498 \\
\hline $\mathrm{iAUC}(\mathrm{mg} \times \mathrm{min} / \mathrm{l})$ & $877^{a, b}$ & 432 & $1227^{\mathrm{a}}$ & 419 & $1161^{\mathrm{a}, \mathrm{b}}$ & 423 & $887^{\mathrm{b}}$ & 592 & 0.006 \\
\hline Maximal change $(\mathrm{mg} / \mathrm{l})$ & $4 \cdot 38$ & 2.02 & $5 \cdot 17$ & 1.63 & 5.43 & 1.60 & $4 \cdot 27$ & $2 \cdot 54$ & 0.076 \\
\hline \multicolumn{10}{|l|}{ Glucose } \\
\hline $\mathrm{iAUC}(\mathrm{mmol} \times \mathrm{min} / \mathrm{l})$ & 213 & 124 & 211 & 150 & 155 & 136 & 242 & 161 & 0.051 \\
\hline Maximal change $(\mathrm{mmol} / \mathrm{l})$ & $3 \cdot 22^{\mathrm{a}}$ & $1 \cdot 10$ & $2 \cdot 79^{a, b}$ & 1.46 & $2.57^{b}$ & 1.46 & $3 \cdot 15^{\mathrm{a}, \mathrm{b}}$ & 1.14 & 0.004 \\
\hline \multicolumn{10}{|l|}{ Insulin } \\
\hline iAUC $(\mathrm{pmol} / \mathrm{l} \times \mathrm{min}) \times 10^{3}$ & $131^{\mathrm{a}}$ & 106 & $185^{\mathrm{b}}$ & 129 & $121^{\mathrm{a}}$ & 91 & $130^{\mathrm{a}, \mathrm{b}}$ & 78 & $<0.001$ \\
\hline Maximal change $(\mathrm{pmol} / \mathrm{l})$ & 1243 & 847 & 1430 & 806 & 1306 & 764 & 1278 & 701 & 0.227 \\
\hline \multicolumn{10}{|l|}{ NEFA } \\
\hline $\mathrm{dAUC}(\mu \mathrm{mol} \times \mathrm{min} / \mathrm{l}) \times 10^{3}$ & $69 \cdot 7$ & $54 \cdot 1$ & $11 \cdot 2$ & $36 \cdot 2$ & $54 \cdot 7$ & $47 \cdot 0$ & $59 \cdot 6$ & $35 \cdot 2$ & 0.218 \\
\hline Maximal change $(\mu \mathrm{mol} / \mathrm{l})$ & -319 & 180 & -356 & 131 & -274 & 188 & -290 & 127 & 0.114 \\
\hline
\end{tabular}

dAUC, decremental AUC.

${ }^{a, b}$ Mean values within a row with unlike superscript letters were significantly different $(P<0.05)$.

meals $(P=0.355$ for meal effect; see supplementary Fig. S3, available online). Minimal values were reached after $120 \mathrm{~min}$. Since NEFA concentrations dropped below the fasting values after meal consumption, decremental AUC instead of iAUC were calculated. The decremental AUC $(P=0.281)$ and the maximal decrease in NEFA $(P=0 \cdot 114)$ were not different between the interventions.

\section{Amino acids}

Plasma concentrations of total, essential and non-essential amino acids after the four meals are given in Table 4). After 60 and $120 \mathrm{~min}$, amino acid concentrations were increased on the milk and protein meals, compared with the control and $\mathrm{Ca}$ meals. Concentrations of the individual amino acids are provided as supplemental data (Supplementary Table S2, available online).

\section{Discussion}

The aim of the present study was to compare the effects of milk and of milk protein and $\mathrm{Ca}$, two major milk constituents, on postprandial lipid and glucose metabolism. Compared with control, milk increased the iAUC for apoB-48 and insulin. Further, the iAUC for TAG was increased and the maximal change in glucose was decreased when protein was added to the meal. The addition of $\mathrm{Ca}$ to the fat-containing meal had no effects on these parameters.

Results from other studies on postprandial effects of protein on TAG responses are not conclusive. Our finding that the addition of milk protein increased the iAUC of TAG contrasts observations of Westphal et al. ${ }^{(11)}$, who found in normalweight men and women no change in this parameter when casein was added to a high-fat, carbohydrate-containing meal. In fact, they even reported that the iAUC for the chylomicron fraction was decreased. In a second study, casein and soya reduced serum TAG concentrations at the early time points, when added to a high-fat meal containing virtually no carbohydrates ${ }^{(15)}$. In that study, iAUC values were not reported, while TAG concentrations were not analysed in the chylomicron and VLDL fractions. The amounts of protein (about $50 \mathrm{~g}$ ) and fat (about $70 \mathrm{~g}$ ) given to the subjects were higher than in the present study. The authors suggested that the decreased chylomicron TAG response ${ }^{(11)}$ resulted from a delayed gastric emptying and from increased insulin concentrations. Insulin activates lipoprotein lipase, which might increase chylomicron degradation ${ }^{(16)}$. The responsiveness of lipoprotein lipase, in adipose tissue, to insulin and meals may be diminished in obesity ${ }^{(17)}$. As the subjects in the present study were all overweight or obese, in contrast to those in the trials of Westphal et al. ${ }^{(11,15)}$, it can be speculated that this might at least partly explain the different findings. However,

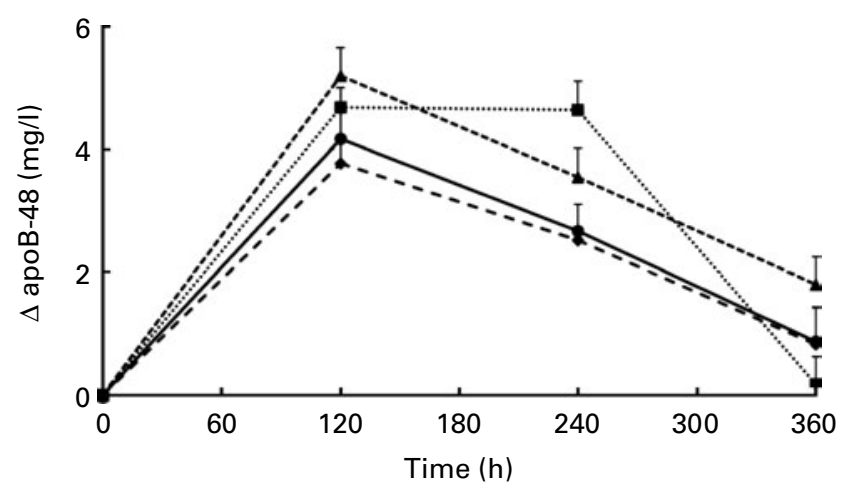

Fig. 2. Mean changes in apoB-48 concentrations after the control, milk, protein, and calcium meals in a randomised crossover study with overweight and obese men ( $n$ 16). Values are means with their standard errors and were analysed using linear mixed models. There were no significant meal $\times$ time interactions. Time effects were $P<0.001$ and meal effects $P=0.016$. After Bonferroni's correction for multiple comparisons, all time points significantly differed from zero: $P<0.001$. In addition, differences between the milk and calcium meals $(P=0.030)$ and between the protein and calcium

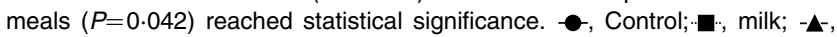
protein; $\triangleleft$, calcium. 
Table 4. Fasting plasma amino acid concentrations and their changes after the test meals (Mean values and standard deviations)

\begin{tabular}{|c|c|c|c|c|c|c|c|c|c|c|c|}
\hline & \multicolumn{2}{|c|}{ Control } & \multicolumn{2}{|c|}{ Milk } & \multicolumn{2}{|c|}{ Protein } & \multicolumn{2}{|c|}{$\mathrm{Ca}$} & \multicolumn{3}{|c|}{$P$} \\
\hline & Mean & SD & Mean & SD & Mean & SD & Mean & SD & Time & Meal & Meal $\times$ diet \\
\hline Total AA $(\mu \mathrm{mol} / \mathrm{l})$ & & & & & & & & & $<0.001$ & $<0.001$ & $<0.001$ \\
\hline Fasting & 2493 & 303 & 2479 & 243 & 2498 & 310 & 2453 & 238 & & & \\
\hline Change after $1 \mathrm{~h}$ & $-126^{a}$ & 127 & $269^{b}$ & 286 & $278^{\mathrm{b}}$ & 384 & $-110^{\mathrm{a}}$ & 234 & & & \\
\hline Change after $2 \mathrm{~h}$ & $-248^{a}$ & 216 & $135^{\mathrm{b}}$ & 287 & $112^{\mathrm{b}}$ & 313 & $-251^{a}$ & 219 & & & \\
\hline $\mathrm{EAA}(\mu \mathrm{mol} / \mathrm{l})$ & & & & & & & & & $<0.001$ & $<0.001$ & $<0.001$ \\
\hline Fasting & 844 & 113 & 835 & 82 & 847 & 89 & 816 & 100 & & & \\
\hline Change after $1 \mathrm{~h}$ & $-103^{a}$ & 45 & $104^{\mathrm{b}}$ & 122 & $107^{b}$ & 103 & $-96^{a}$ & 81 & & & \\
\hline Change after $2 \mathrm{~h}$ & $-191^{a}$ & 72 & $42^{\mathrm{b}}$ & 102 & $26^{\mathrm{b}}$ & 92 & $-177^{\mathrm{a}}$ & 87 & & & \\
\hline NEAA $(\mu \mathrm{mol} / \mathrm{l})$ & & & & & & & & & $<0.001$ & $<0.001$ & $<0.001$ \\
\hline Fasting & 1649 & 220 & 1644 & 183 & 1651 & 251 & 1636 & 169 & & & \\
\hline Change after $1 \mathrm{~h}$ & $-24^{a}$ & 97 & $165^{\mathrm{b}}$ & 181 & $171^{b}$ & 290 & $-14^{a}$ & 162 & & & \\
\hline Change after $2 \mathrm{~h}$ & $-57^{a, b}$ & 157 & $93^{c}$ & 199 & $86^{\mathrm{b}, \mathrm{c}}$ & 242 & $-74^{\mathrm{a}}$ & 140 & & & \\
\hline
\end{tabular}

AA, amino acids; EAA, essential amino acids (methionine, threonine, valine, isoleucine, leucine, phenylalanine, lysine, tryptophan); NEAA, non-essential amino

a,b,cids.

in a trial with overweight, type 2 diabetic subjects, Brader et $a{ }^{(18)}$ did find a decrease in TAG after casein consumption, but only in combination with carbohydrate consumption. Cohen ${ }^{(19)}$ observed no effects of casein addition (23g) on postprandial lipaemia after a high-fat $(40 \mathrm{~g})$ meal in normalweight men and women. One study has reported increased TAG concentrations after fat and casein consumption in healthy male subjects ${ }^{(20)}$. However, since only four out of six subjects showed increased postprandial lipaemia after protein ingestion and results were not statistically analysed, the findings of that study are difficult to interpret. The protein we used was a total milk protein, containing the total fraction of cows' milk (mainly casein and whey), and thus somewhat different from the protein used by Westphal et al. ${ }^{(11)}$. Animal studies suggest that casein may have an unfavourable impact on lipid metabolism, as compared with soya protein ${ }^{(21)}$, but human studies suggest that the nature of protein does not affect postprandial lipaemia ${ }^{(15)}$. We further provided the protein in addition to that in the meals, resulting in a higher energy intake in the protein and milk meals. However, it is not likely that a higher energy intake per se will increase postprandial TAG concentrations. For example, when extra energy is added to a fat-rich meal in the form of glucose, the TAG response may even be reduced ${ }^{(22,23)}$.

We further observed that apoB-48 responses increased by the addition of milk or protein to the meal, which is in line with our observations on TAG responses. ApoB-48 is the apo present on chylomicrons of intestinal origin. The present results therefore imply that after the protein and milk meal, the number of chylomicron particles in the circulation is higher compared with the control meal. Whether this is due to an increased production or to a decreased clearance remains unknown.

The Ca supplement used in the present trial, which was derived from a dairy source, did not affect the serum TAG response. Lorenzen et al. ${ }^{(12)}$ found that $\mathrm{Ca}$ from dairy products (350 or $800 \mathrm{mg}$ ), but not a calcium carbonate supplement ( $850 \mathrm{mg}$ ), reduced the iAUC for chylomicron TAG after a fat load. The authors suggested that this decrease may be due to a reduction in fat absorption, as a number of studies have shown that $\mathrm{Ca}$ intake increases faecal fat excretion, probably through the binding in the intestine of $\mathrm{Ca}$ to fatty acids, mainly SFA ${ }^{(24)}$. However, no differences in total plasma TAG were observed, which is in line with our findings. Effects on fat absorption, however, cannot be fully excluded, as the effect on chylomicron TAG may have been too small to be detected in the total TAG fraction or may have been counteracted by an increase in VLDL.

We observed a $35 \%$ increase in the insulin response after the milk meal, but no increase after the protein meal. Protein, especially in combination with carbohydrates, is already known for decades to induce insulin secretion ${ }^{(25)}$. Van Loon et al. ${ }^{(26-28)}$ confirmed the insulinotropic potential of various proteins, hydrolysates and free amino acids in combination with carbohydrates in a series of studies in healthy young subjects. One of the most insulinotropic amino acids was leucine, which is highly present in milk protein. In addition, protein may decrease hepatic insulin extraction from the circulation. Addition of whey protein to a meal resulted in elevated postprandial insulin concentrations, while C-peptide levels were unaffected $^{(29)}$. However, Westphal et al. ${ }^{(11)}$ did find increased C-peptide concentrations after casein consumption, indicating an increased insulin production. Our observation that the insulin response was elevated by the milk meal, but not by the protein meal, is unexpected, as the protein content, the source of protein, the amino acid composition and the $\mathrm{Ca}$ and lactose content were exactly the same in both drinks. Further, changes in plasma concentrations of amino acids were comparable after the milk and protein meal. So, there may be an additional factor in milk that influences either the secretion or the clearance of insulin.

The iAUC for glucose were not different between the meals, but the peak change was decreased by the protein meal. Milk also decreased the peak change in glucose, though this change did not reach statistical significance. Ca had no effect. Thus, we observed a reduction in the maximal glucose 
concentration, while the insulin response was not changed after the protein meal. A number of amino acids, including lysine $e^{(30)}$, proline $e^{(31)}$, glycine ${ }^{(32)}$ and arginine ${ }^{(33)}$, have been found to attenuate plasma glucose levels when ingested with carbohydrates, without elevating insulin concentrations. However, other amino acids, such as leucine ${ }^{(34)}$ and phenylalanine $^{(35)}$, have been shown to cause a reduction in plasma glucose and a concurrent increase in insulin secretion. The increased insulin levels after the milk diet did not affect NEFA concentrations. This is in contrast to the reduced NEFA concentrations observed by Westphal et al. ${ }^{(11,15)}$, who contributed this effect to the increased insulin response. However, Brader et al. $^{(18)}$ did not find significant differences in NEFA AUC, despite an increase in insulin after casein consumption.

In conclusion, the present results indicate that the intake of milk with a fat-containing meal enhances postprandial TAG and insulin responses and may blunt glucose increases. The protein fraction of milk seems to be the main determinant for the effects on TAG and glucose. Ca did not change any of the postprandial responses.

\section{Supplementary material}

To view supplementary material for this article, please visit http://dx.doi.org/10.1017/S0007114512005314

\section{Acknowledgements}

The present study was financially supported by the Dutch Dairy Association (Nederlandse Zuivel Organisatie). We would like to thank Martine Hulsbosch and Denis van Beurden for their technical support and Yvonne Verhulst for her dietary assistance. L. E. C. V. M. conducted the study. R. P. M. designed the study and had overall responsibility. L. E. C. V. M. and R. P. M. analysed the data and wrote the manuscript. All authors read and approved the final manuscript. The authors report no conflict of interest.

\section{References}

1. Coutinho M, Gerstein HC, Wang Y, et al. (1999) The relationship between glucose and incident cardiovascular events. A metaregression analysis of published data from 20 studies of 95,783 individuals followed for 12.4 years. Diabetes Care 22, $233-240$

2. Karpe F (1999) Postprandial lipoprotein metabolism and atherosclerosis. J Intern Med 246, 341-355.

3. Bansal S, Buring JE, Rifai N, et al. (2007) Fasting compared with nonfasting triglycerides and risk of cardiovascular events in women. JAMA 298, 309-316.

4. Temelkova-Kurktschiev TS, Koehler C, Henkel E, et al. (2000) Postchallenge plasma glucose and glycemic spikes are more strongly associated with atherosclerosis than fasting glucose or HbA1c level. Diabetes Care 23, 830-834.

5. Carroll MF, Izard A, Riboni K, et al. (2002) Fasting hyperglycemia predicts the magnitude of postprandial hyperglycemia: implications for diabetes therapy. Diabetes Care $\mathbf{2 5}$, $1247-1248$.
6. Van Wijk JP, Halkes CJ, Erkelens DW, et al. (2003) Fasting and daylong triglycerides in obesity with and without type 2 diabetes. Metabolism 52, 1043-1049.

7. Van Oostrom AJ, Alipour A, Plokker TW, et al. (2007) The metabolic syndrome in relation to complement component 3 and postprandial lipemia in patients from an outpatient lipid clinic and healthy volunteers. Atherosclerosis 190, $167-173$.

8. Dubois C, Beaumier G, Juhel C, et al. (1998) Effects of graded amounts $(0-50 \mathrm{~g})$ of dietary fat on postprandial lipemia and lipoproteins in normolipidemic adults. Am J Clin Nutr 67, 31-38.

9. Vogel RA, Corretti MC \& Plotnick GD (1997) Effect of a single high-fat meal on endothelial function in healthy subjects. $\mathrm{Am}$ J Cardiol 79, 350-354.

10. Aljada A, Mohanty P, Ghanim H, et al. (2004) Increase in intranuclear nuclear factor kappaB and decrease in inhibitor kappaB in mononuclear cells after a mixed meal: evidence for a proinflammatory effect. Am J Clin Nutr 79, 682-690.

11. Westphal S, Kästner S, Taneva E, et al. (2004) Postprandial lipid and carbohydrate responses after the ingestion of a casein-enriched mixed meal. Am J Clin Nutr 80, 284-290.

12. Lorenzen JK, Nielsen S, Holst JJ, et al. (2007) Effect of dairy calcium or supplementary calcium intake on postprandial fat metabolism, appetite, and subsequent energy intake. Am J Clin Nutr 85, 678-687.

13. Friedewald WT, Levy RI \& Fredrickson DS (1972) Estimation of the concentration of low-density lipoprotein cholesterol in plasma, without use of the preparative ultracentrifuge. Clin Chem 18, 499-502.

14. Van Eijk HM, Rooyakkers DR \& Deutz NE (1993) Rapid routine determination of amino acids in plasma by highperformance liquid chromatography with a $2-3$ microns Spherisorb ODS II column. J Chromatogr 620, 143-148.

15. Westphal S, Taneva E, Kästner S, et al. (2006) Endothelial dysfunction induced by postprandial lipemia is neutralized by addition of proteins to the fatty meal. Atherosclerosis 185, 313-319.

16. Eckel RH (1989) Lipoprotein lipase. A multifunctional enzyme relevant to common metabolic diseases. $N$ Engl J Med 320, 1060-1068.

17. Wang H \& Eckel RH (2009) Lipoprotein lipase: from gene to obesity. Am J Physiol Endocrinol Metab 297, E271-E288.

18. Brader L, Holm L, Mortensen L, et al. (2009) Acute effects of casein on postprandial lipemia and incretin responses in type 2 diabetic subjects. Nutr Metab Cardiovasc Dis 20, 101-109.

19. Cohen JC (1989) Protein ingestion does not affect postprandial lipaemia or chylomicron-triglyceride clearance. Eur J Clin Nutr 43, 497-499.

20. Sullivan JF (1962) The effect of protein ingestion on alimentary lipemia. Am J Med Sci 243, 770-774.

21. Oliva ME, Selenscig D, D'Alessandro ME, et al. (2011) Soya protein ameliorates the metabolic abnormalities of dysfunctional adipose tissue of dyslipidaemic rats fed a sucrose-rich diet. Br J Nutr 105, 1188-1198.

22. Cohen JC \& Berger GM (1990) Effects of glucose ingestion on postprandial lipemia and triglyceride clearance in humans. J Lipid Res 31, 597-602.

23. Westphal S, Leodolter A, Kahl S, et al. (2002) Addition of glucose to a fatty meal delays chylomicrons and suppresses VLDL in healthy subjects. Eur J Clin Invest 32, 322-327.

24. Denke MA, Fox MM \& Schulte MC (1993) Short-term dietary calcium fortification increases fecal saturated fat content and reduces serum lipids in men. J Nutr 123, 1047-1053. 
25. Rabinowitz D, Merimee TJ, Maffezzoli R, et al. (1966) Patterns of hormonal release after glucose, protein, and glucose plus protein. Lancet ii, 454-456.

26. Van Loon LJ, Kruijshoop M, Verhagen H, et al. (2000) Ingestion of protein hydrolysate and amino acid-carbohydrate mixtures increases postexercise plasma insulin responses in men. J Nutr 130, 2508-2513.

27. Van Loon LJ, Saris WH, Kruijshoop M, et al. (2000) Maximizing postexercise muscle glycogen synthesis: carbohydrate supplementation and the application of amino acid or protein hydrolysate mixtures. Am J Clin Nutr 72, 106-111.

28. Van Loon LJ, Saris WH, Verhagen H, et al. (2000) Plasma insulin responses after ingestion of different amino acid or protein mixtures with carbohydrate. Am J Clin Nutr $\mathbf{7 2 ,}$ 96-105.

29. Lan-Pidhainy X \& Wolever TM (2010) The hypoglycemic effect of fat and protein is not attenuated by insulin resistance. Am J Clin Nutr 91, 98-105.

30. Kalogeropoulou D, LaFave L, Schweim K, et al. (2009) Lysine ingestion markedly attenuates the glucose response to ingested glucose without a change in insulin response. $A m$ J Clin Nutr 90, 314-320.

31. Nuttall FQ, Gannon MC \& Jordan K (2004) The metabolic response to ingestion of proline with and without glucose. Metabolism 53, 241-246.

32. Gannon MC, Nuttall JA \& Nuttall FQ (2002) The metabolic response to ingested glycine. Am J Clin Nutr 76, 1302-1307.

33. Gannon MC, Nuttall JA \& Nuttall FQ (2002) Oral arginine does not stimulate an increase in insulin concentration but delays glucose disposal. Am J Clin Nutr 76, 1016-1022.

34. Kalogeropoulou D, Lafave L, Schweim K, et al. (2008) Leucine, when ingested with glucose, synergistically stimulates insulin secretion and lowers blood glucose. Metabolism 57, 1747-1752.

35. Nuttall FQ, Schweim KJ \& Gannon MC (2006) Effect of orally administered phenylalanine with and without glucose on insulin, glucagon and glucose concentrations. Horm Metab Res 38, 518-523. 